\title{
PENERAPAN METODE ANALYTICAL HIERARCHY PROCESS (AHP) DAN SIMPLE ADDITIVE WEIGHTING (SAW) UNTUK PENENTUAN PENERIMA BANTUAN SOSIAL PANDEMI COVID-19
}

\author{
Nidya Kusumawardhany \\ Fakultas Teknologi Informasi, Universitas Budi Luhur \\ J1. Raya Ciledug, Petukangan Utara, Kebayoran Lama, Jakarta Selatan 12260 \\ E-mail : nidya.kusumawardhany@budiluhur.ac.id
}

\begin{abstract}
Abstrak
Pandemi COVID-19 tidak hanya mengakibatkan peningkatan jumlah kasus positif yang disebabkan dari berbagai reaksi masyarakat yang kurang peduli dengan wabah ini, namun juga diikuti dengan peningkatan angka kemiskinan, mobilitas masyarakat secara dini, serta kerawanan keamanan. Pemerintah berencana memberikan bantuan sosial khusus untuk masyarakat golongan menengah ke bawah dalam menghadapi pandemi COVID-19 ini. Penyaluran bantuan sosial sebagai realisasi dari program jaring pengaman sosial selama pandemi COVID-19 menyisakan banyak pekerjaan rumah. Mulai dari pendataan, ketepatan target penerima bantuan, hingga penyalurannya. Mekanisme penyaluran bantuan menjadi rumit dan sering kali kurang tepat sasaran karena kriteria penerima bantuan yang tidak sesuai dan data yang tidak akurat/tidak sesuai dengan kenyataan di lapangan. Hingga terjadi protes dari warga yang seharusnya mendapatkan bantuan tetapi mereka tidak mendapatkan bantuan tersebut, begitupun sebaliknya. Penelitian ini mengusulkan metode Analytical Hierarchy Process (AHP) untuk pembobotan nilai setiap kriteria dan metode Simple Additive Weighting (SAW) untuk perankingannya. Penelitian ini menghasilkan nilai bobot kriteria Status pekerjaan kepala keluarga sebesar 0,425, Status pekerjaan istri sebesar 0,166, Status rumah sebesar 0,094, jumlah tanggungan sebesar 0,056 dan KTP sebesar 0,259 dengan nilai consistency ratio sebesar 0,09 .
\end{abstract}

Kata Kunci : Bantuan sosial, Pandemi, COVID-19, AHP, SAW.

\section{PENDAHULUAN}

Pandemi COVID-19 tidak hanya mengakibatkan peningkatan jumlah kasus positif yang disebabkan dari berbagai reaksi masyarakat yang kurang peduli dengan wabah ini, namun juga diikuti dengan peningkatan angka kemiskinan, mobilitas masyarakat secara dini, serta kerawanan keamanan.

Pemerintah berencana memberikan bantuan sosial khusus untuk masyarakat golongan menengah ke bawah dalam menghadapi pandemi COVID-19 ini. Bantuan tersebut, ada yang terdiri dari bantuan non tunai berupa paket sembako dan bantuan tunai berupa uang. Penentuan siapa yang berhak menerima bantuan perlu dilakukan dengan sangat hati-hati agar bantuan yang diberikan tepat sasaran dan memenuhi azas keadilan bagi semua.

Rukun Warga 016, yang merupakan bagian Kelurahan paninggilan Utara, Kecamatan Ciledug, Kota Tangerang, adalah salah satu RW yang berada di Perumahan Griya Ciledug, yang memiliki Satgas Siaga Corona (SIGACOR). Dalam penanganan penyebaran Covid-19 di lingkungan RW 016, selain bertugas melaksanakan Protokol Kesehatan di lingkungan RW 016, juga bertugas melakukan pemberian bantuan sosial kepada seluruh warga yang terdampak secara ekonomi di lingkungan RW 016.

Penyaluran bantuan sosial sebagai realisasi dari program jaring pengaman sosial selama pandemi COVID-19 memang menyisakan banyak pekerjaan rumah. Mulai dari pendataan, ketepatan target penerima, hingga penyalurannya. Penerimaan bantuan dari kelurahan yang di terima oleh RW tidak mencukupi untuk membatu semua warga yang mendaftarkan diri terdampak secara ekonomi karena pandemi Covid-19, sehingga perlu ditetapkan prioritas warga yang benar benar membutuhkan untuk diberi bantuan sosial, kemudian belum adanya kriteria dan pembobotan yang tepat dari masing masing kriteria dalam penentuan penerima bantuan sosial pada saat pandemi Covid 19, sehingga tidak tepat sasaran yang menimbulkan protes dari warga yang seharusnya mendapatkan bantuan tetapi mereka tidak mendapatkan bantuan tersebut, begitupun sebaliknya. Mekanime penyaluran bantuan belum menggunakan metode yang tepat dalam menentukan penerima bantuan sosial pada saat pandemi Covid-19, sehingga tingginya subyektifitas dalam penentuan penerima bantuan sosial tersebut.

Dalam menyelesaikan permasalahan yang terjadi dalam penentuan penerima bantuan Covid-19, dibutuhkan sebuah sistem pendukung keputusan yang merupakan suatu pendekatan untuk mendukung pengambilan keputusan. Sistem pendukung keputusan menggunakan data, memberikan antarmuka pengguna yang mudah, dan dapat menggabungkan pemikiran pengambil keputusan[1].

Penelitian-penelitian sebelumnya terkait dengan metode pendukung keputusan dalam menentukan penerima bantuan telah dilakukan dengan metode AHP oleh Metode AHP [2][3], Metode AHPPROMETHEE [4], Metode ELECTRE [5], Metode 
MOORA [6], Metode SAW [7], Metode TOPSIS [8], dan Metode Weighted Product [9][10].

Berdasarkan data-data yang telah didapatkan berkaitan dengan bantuan sosial saat pandemi COVID-19, maka penelitian ini fokus pada penerapan metode Analytical Hierarchy Process (AHP) dan Simple Additive Weighting (SAW) untuk penentuan penerima bantuan sosial pada saat pandemi Covid-19 yang sesuai dengan kriteriakriteria yang ditetapkan sehingga dapat lebih tepat sasaran, efektif dan berkeadilan.

\section{METODE PENELITIAN}

\section{a. Metode Pengumpulan Data}

Dalam penelitian ini untuk mengumpulkan data penulis melakukan studi pustakan dan observasi dengan wawancara. Observasi yang dilakukan dengan terjun langsung ke wilayah tempat pembagian bantuan non tunai di wilayah RW 016 Kelurahan Paninggilan Utara. Wawancara dilakukan pada pihak-pihak yang menangani langsung pendistribusian bantuan non tunai, baik dari pihak Kelurahan maupun RW setempat.

\section{b. Teknik Analisa Data}

Teknik analisa data yang digunakan pada penelitian ini menggunakan analisis deskriptif, AHP dan SAW. Analisis deskriptif dilakukan dengan menyajikan rangkuman yang diperoleh dari hasil observasi dan wawancara. Sedangkan AHP dan SAW sebagai instrumen untuk menentukan siapa yang paling tepat menerima bantuan sesuai dengan kriteria yang telah disepakati/ditetapkan oleh pihak pemberi bantuan (Kelurahan/RW setempat). AHP untuk menghitung pembobotan, karena belum adanya bobot kriteria untuk perhitungan penentuan jurusan siswa dan SAW untuk menentukan perankingan penerima bantuan.

\section{c. Teknik Pengujian}

Teknik pengujian untuk model SPK menggunakan metode Consitency Ratio (CR).

\section{HASIL DAN PEMBAHASAN}

Setelah melaksanakan tahap demi tahap langkah-langkah penelitian maka didapatkan hasil berupa kriteria-kriteria dan alternatif bagi calon penerima penerima bantuan sosial pandemi Covid-19. Data yang didapat dari RT/RW setempat diolah menggunakan metode AHP untuk mendapatkan bobot dari masing masing kritera, setelah mendapatkan nilai bobot, selanjutnya diolah lagi menggunakan metode SAW untuk menentukan ranking calon penerima bantuan.

Perangkingan ini diperlukan karena bantuan yang diberikan terbatas, sehingga tidak semua calon penerima dapat menerima bantuan tersebut.

Dengan adanya penerapan metode AHP dan SAW ini, pengurus RT/RW dapat dengan mudah memberikan daftar nama penerima bantuan yang obyektif, karena data diolah secara terbuka/transparan, kriteria-kriteria ditetapkan bersama dalam kelembagaan RT/RW sehingga warga/penduduk tidak perlu curiga tentang penyaluran bantuan tersebut.

\subsection{Identifikasi Kriteria}

Dalam mengidentifikasi Kriteria kriteria yang di gunakan untuk menentukan penerima bantuan sosial pandemi Covid-19 dilakukan dengan teknik wawancara yang melibatkan ketua RT, RW dan Satgas SIGACOR RW 016, sehingga dihasilkan kriteria-kriteria penerima bantuan seperti terlihat pada Tabel 3.1.

Tabel 3.1. Kriteria-kriteria Penerima Bantuan

\begin{tabular}{|c|l|l|c|}
\hline No. & \multicolumn{1}{|c|}{ Kriteria } & \multicolumn{1}{|c|}{ Keterangan Nilai } & Fungsi \\
\hline 1 & $\begin{array}{l}\text { Status Pekerjaan } \\
\text { kepala keluarga }\end{array}$ & $\begin{array}{l}\text { Ojol =1, } \\
\text { Dirumahkan=2, } \\
\text { Wirausaha terhenti=3, } \\
\text { PHK=4 }\end{array}$ & Benefit (+) \\
\hline 2 & Status Pekerjaan Istri & Bekerja =2, RT =1 & Cost (-) \\
\hline 3 & Status Rumah & $\begin{array}{l}\text { Kontrak =1, Milik } \\
\text { Sendiri =2 }\end{array}$ & Cost (-) \\
\hline 4 & $\begin{array}{l}\text { Jumlah Tanggungan } \\
\text { Serumah }\end{array}$ & $\begin{array}{l}\text { Jumlah tanggungan } \\
\text { Tangerang=2, Luar } \\
\text { Tangerang =1 }\end{array}$ & Benefit(+) \\
\hline 5 & KTP & Benefit (+) \\
\hline
\end{tabular}

\subsection{Struktur Kriteria menggunakan metode AHP}

Setelah di tentukan kriteria penerima bantuan, maka selanjutnya membuat Struktur Hirarki AHP seperti terlihat pada Gambar 3.1.

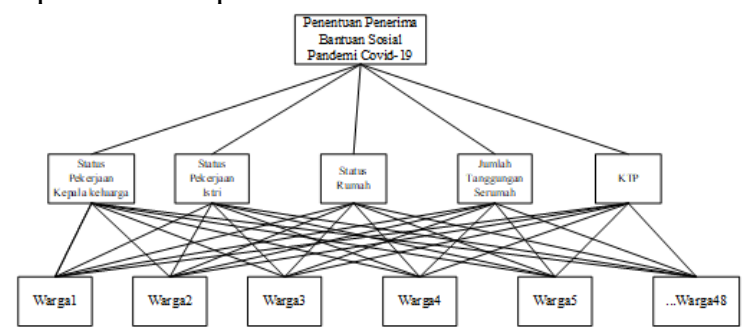

Gambar 3.1. Struktur Hirarki AHP Penentuan Penerima Bantuan Sosial

Pada Gambar 3.1 terlihat bahwa pada layer pertama terdapat Tujuan (Goal) dari penelitian ini yaitu penentuan penerima bantuan sosial pandemi Covid-19, kemudian pada layer ke 2, terdapat 5 (lima) kriteria yaitu status pekerjaan kepala keluarga, status pekerjaaan Istri, status rumah, jumlah tanggugan serumah dan KTP, dan pada layer ke 3 adalah Alternatif atau calon penerima bantuan yang telah mengajukan kepada Satgas SIGACOR RW 016 yang berjumlah 48 warga.

Tahap selanjutnya adalah menentukan nilai dari masing-masing kriteria menggunakan kuisioner AHP, menggunakan penilaian Perbandingan berpasangan seperti terlihat pada Tabel 3.2.

Tabel 3.2. Nilai Pperbandingan Antar Kritera metode AHP

\begin{tabular}{|c|c|c|c|c|c|}
\hline Kriteria & SPKK & SPI & Status rumah & Jml Tanggungan & KTP \\
\hline SPKK & 1 & 3 & 4 & 4 & 3 \\
\hline SPI & $1 / 3$ & 1 & 3 & 4 & $1 / 3$ \\
\hline Status Rumah & $1 / 4$ & $1 / 3$ & 1 & 3 & $1 / 3$ \\
\hline Jml Tanggungan & $1 / 4$ & $1 / 4$ & $1 / 3$ & 1 & $1 / 4$ \\
\hline KTP & $1 / 3$ & 3 & 3 & 4 & 1 \\
\hline
\end{tabular}


Berdasarkan nilai perbandingan antar kriteria, kemudian dilakukan perhitungan dengan menggunakan metode AHP. Pada penelitian ini perhitungan nilai perbandingan antar kriteria menggunakan software expert choice versi 11 yang hasilnya terlihat pada Gambar 3.2.

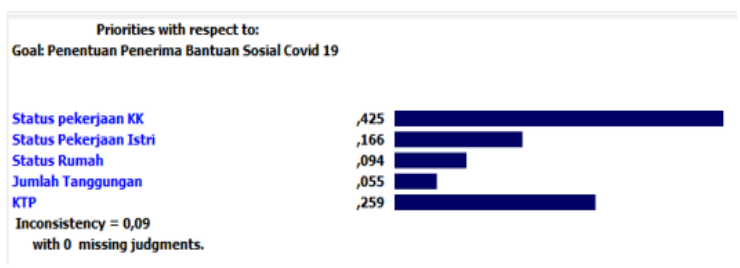

Gambar 3.2. Nilai Bobot dari Masing Kriteria

Hasil Eigenvector (bobot) dari masing masing kriteria dapat dilihat pada Tabel 3.3.

Tabel 3.3. Nilai Eigenvector Masing masing kriteria

\begin{tabular}{|l|r|}
\hline \multicolumn{1}{|c|}{ Kriteria } & \multicolumn{1}{c|}{ Nilai Bobot } \\
\hline SPKK & 0,425 \\
\hline SPI & 0,166 \\
\hline Status Rumah & 0,094 \\
\hline Jml Tanggungan & 0,056 \\
\hline KTP & 0,259 \\
\hline Total & 1 \\
\hline
\end{tabular}

Berdasarkan Tabel 3.3, Kriteria yang paling penting dalam menentukan calon penerima bantuan sosial saat pandemi Covid-19 adalah Kriteria Status Pekerjaan kepala keluarga (SPKK) sebesar 0,425, kedua adalah kriteria Status Pekerjaan Istri (SPI) sebesar 0,1666, ketiga adalah kriteria Status rumah sebesar 0,094, keempat adalah kriteria jumlah tanggungan sebesar 0,056 dan kelima adalah kriteria KTP.

\subsection{Pengujian Metode AHP Penentuan Penerima Bantuan Sosial}

Pengujian model AHP dilakukan dengan cara menghitung nilai Consistency Index (CI) dan Nilai Consistency Ratio (CR)

a) Perhitungan Consistensi Index (CI)

Pengukuruan ini dimaksudkan agar dapat diketahui konsistensi jawaban yang akan berpengaruh kepada kesahihan hasil [11]. Rumus CI dapat dilihat pada persamaan (3.1)

$$
C I=\frac{\lambda \max -n}{n-1}
$$

Untuk mengetahui CI dengan besaran tertentu cukup baik atau tidak, maka perlu diketahui Consistency Ratio (CR) yang dianggap baik, yaitu apabila $\mathrm{CR} \approx 0.1$. Rumus $\mathrm{CR}$ dapat dilihat pada persamaan (3.2).

$$
C R=\frac{C I}{R I}
$$

Nilai Random Index (RI) merupakan nilai yang dikeluarkan oleh Oarkridge laboratory [11], yang berupa tabel seperti terlihat pada tabel 3.4.
Tabel 3.4. Nilai Random Index (Oarkridge Laboratory)

\begin{tabular}{|c|c|c|c|c|c|c|c|c|c|c|c|c|c|}
\hline $\mathbf{N}$ & 1 & 2 & 3 & 4 & 5 & 6 & 7 & 8 & 9 & 10 & 11 & 12 & 13 \\
\hline $\mathbf{R I}$ & 0,00 & 0,00 & 0,58 & 0,90 & 1,12 & 1,24 & 1,32 & 1,41 & 1,45 & 1,49 & 1,51 & 1,48 & 1,56 \\
\hline
\end{tabular}

b) Perhitungan Consistency Ratio (CR)

Consistency Ratio merupakan parameter yang digunakan untuk memeriksa perbandingan berpasangan telah dilakukan dengan konsekuen atau tidak [11]. Dari Hasil perhitungan yang terlihat pada gambar 3.2 menghasilkan Consitency Ratio sebesar 0.09, ini Artinya bahwa penilaian perbandingan dikatakan konsisten jika CR tidak lebih dari 0.10, sehingga penilaian perbandingan kriteria penerima bantuan sosial sudah konsisten dan tidak memerlukan revisi penilaian.

\subsection{Identifikasi Alternatif}

Calon penerima bantuan pandemi Covid-19 yang telah mendaftar melalui RT dilingkungan RW 016, berjumlah 48 warga dengan rincian seperti terlihat pada Tabel 3.5.

Tabel 3.5. Jumlah Calon penerima bantuan Pandemi Covid 19 RW 016

\begin{tabular}{|r|l|r|}
\hline \multicolumn{1}{|c|}{ No. } & RT & \multicolumn{1}{|c|}{ Jumlah } \\
\hline 1 & 001 & 10 \\
\hline 2 & 002 & 6 \\
\hline 3 & 003 & 9 \\
\hline 4 & 004 & 12 \\
\hline
\end{tabular}

\subsection{Perangkingan Alternatif Menggunakan Metode SAW}

Setelah mengetahui kriteria penerima bantuan sosial pandemi Covid-19, maka langkah selanjutnya menentukan Perankingan penerima bantuan sosial menggunakan metode SAW. Proses penentuan ranking metode SAW adalah sebagai berikut :

a) Menentukan fungsi benefit (semakin tinggi nilainya semakin baik) atau fungsi Cost (semakin rendah nilainya semakin baik) dari setiap kriteria penerima bantuan sosial. Seperti terlihat pada Tabel 3.6.

b) Setelah diketahui Fungsi Benefit (+) dan Fungsi Cost (-) dari setiap kriteria seperti terlihat pada tabel 3.6, maka selanjutnya dilakukan perhitungan nilai dari masing-masing Alternatif pada matrik awal dengan ketentuan :

1) Fungsi Benefit (+) dihitung dengan rumus nilai pada cell dibagi dengan nilai max pada kolom.

2) Fungsi Cost (-) dihitung dengan rumus nilai MIN pada Kolom dibagi nilai pada Cell.

Tabel 3.6. Fungsi Kriteria Penerima Bantuan Sosial

\begin{tabular}{|c|l|l|c|}
\hline No. & \multicolumn{1}{|c|}{ Kriteria } & \multicolumn{1}{|c|}{ Keterangan Nilai } & Fungsi \\
\hline 1 & $\begin{array}{l}\text { Status Pekerjaan } \\
\text { kepala keluarga }\end{array}$ & $\begin{array}{l}\text { Ojol =1, } \\
\text { Dirumahkan=2, } \\
\text { Wirausaha terhenti=3, } \\
\text { PHK=4 }\end{array}$ & Benefit (+) \\
\hline 2 & Status Pekerjaan Istri & Bekerja =2, IRT =1 & Cost (-) \\
\hline 3 & Status Rumah & $\begin{array}{l}\text { Kontrak =1, Milik } \\
\text { Sendiri =2 }\end{array}$ & Cost (-) \\
\hline 4 & $\begin{array}{l}\text { Jumlah Tanggungan } \\
\text { Serumah }\end{array}$ & $\begin{array}{l}\text { Jumlah tanggungan } \\
\text { Tangerang=2, Luar } \\
\text { Tangerang =1 }\end{array}$ & Benefit(+) \\
\hline 5 & KTP & \multicolumn{2}{|l}{ Benefit (+) } \\
\hline
\end{tabular}


c) Setelah itu dilakukan perhitungan nilai setiap Alternatif dengan cara melakukan perkalian dari hasil Nilai matriks normalisasi setiap Alternatif per kriteria dengan bobot per kriteria yang telah dihasilkan dari proses perhitungan metode AHP.

\subsection{Simulasi Perhitungan Alternatif Menggunakan Metode SAW}

Nilai awal dari Alternatif calon penerima bantuan sosial pandemi Covid-19 dapat dilihat pada Tabel 3.7.

Tabel 3.7. Nilai Awal Simulasi Calon Penerima Bantuan Sosial

\begin{tabular}{|c|c|c|c|c|c|c|}
\hline \multirow{2}{*}{ No } & & \multicolumn{5}{|c|}{ Kriteria } \\
\cline { 3 - 7 } & Alternatif & SPKK & SPI & $\begin{array}{c}\text { Status } \\
\text { Rumah }\end{array}$ & $\begin{array}{c}\text { Jml } \\
\text { Tanggungan }\end{array}$ & KTP \\
\hline 1 & Warga1 & 1 & 1 & 1 & 2 & 2 \\
\hline 2 & Warga2 & 3 & 2 & 2 & 4 & 2 \\
\hline 3 & Warga3 & 2 & 2 & 1 & 5 & 2 \\
\hline 4 & Warga4 & 4 & 1 & 1 & 3 & 1 \\
\hline 5 & Warga5 & 2 & 2 & 2 & 2 & 1 \\
\hline & Bobot & 0.425 & 0.166 & 0.094 & 0.056 & 0.259 \\
\hline
\end{tabular}

Berdasarkan Tabel 3.7, maka dilakukan perhitungan menggunakan metode SAW, sehingga menghasilkan Nilai normalisasi seperti yang terlihat pada Tabel 3.8.

Tabel 3.8. Nilai Normalisasi calon penerima bantuan sosial

\begin{tabular}{|r|l|r|r|r|r|r|c|}
\hline \multirow{2}{*}{} & & \multicolumn{7}{|c|}{ Kriteria } \\
\cline { 3 - 8 } No & Alternatif & SPKK & SPI & $\begin{array}{r}\text { Status } \\
\text { Rumah }\end{array}$ & $\begin{array}{c}\text { Jml } \\
\text { Tanggungan }\end{array}$ & KTP & $\begin{array}{c}\text { Total } \\
\text { Nilai }\end{array}$ \\
\hline 1 & Warga1 & 0.25 & 1 & 1 & 0.4 & 1 & 0.6477 \\
\hline 2 & Warga2 & 0.75 & 0.5 & 0.5 & 0.8 & 1 & 0.7526 \\
\hline 3 & Warga3 & 0.5 & 0.5 & 1 & 1 & 1 & 0.7045 \\
\hline 4 & Warga4 & 1 & 1 & 1 & 0.6 & 0.5 & 0.8481 \\
\hline 5 & Warga5 & 0.5 & 0.5 & 0.5 & 0.4 & 0.5 & 0.4944 \\
\hline
\end{tabular}

Berdasarkan hasil yang didapat pada tabel 3.8, maka dilakukan perangkingan dari semua nilai Alternatif metode SAW seperti terlihat pada tabel 3.9.

Tabel 3.9. Hasil Perangkingan Alternatif

\begin{tabular}{|c|l|r|}
\hline No & Alternatif & Total Nilai \\
\hline 1 & Warga4 & 0.8481 \\
\hline 2 & Warga2 & 0.7526 \\
\hline 3 & Warga3 & 0.7045 \\
\hline 4 & Warga1 & 0.6477 \\
\hline 5 & Warga5 & 0.4944 \\
\hline
\end{tabular}

\subsection{Hasil Penelitian}

Hasil penelitian dari 48 calon penerima bantuan sosial saat pandemi Covid-19 di lingkungan RW 016 perumahan Griya Ciledug, berdasarkan 20 warga teratas dapat dilihat pada Tabel 3.10.
Tabel 3.10. Peringkat Top 20 Calon Penerima Bantuan Sosial Saat Pandemi Covid 19

\begin{tabular}{|r|l|r|r|r|r|r|c|}
\hline No. & Nama & SPKK & \multicolumn{1}{|c|}{ SPI } & \multicolumn{1}{c|}{ SR } & $\begin{array}{c}\text { Jml } \\
\text { Tanggungan }\end{array}$ & KTP & Hasil \\
\hline 1 & Warga4 & 1 & 1 & 1 & 0.6 & 0.5 & 0.8481 \\
\hline 2 & Warga8 & 1 & 1 & 1 & 0.6 & 0.5 & 0.8481 \\
\hline 3 & Warga9 & 1 & 1 & 1 & 0.6 & 0.5 & 0.8481 \\
\hline 4 & Warga11 & 1 & 1 & 1 & 0.6 & 0.5 & 0.8481 \\
\hline 5 & Warga14 & 1 & 1 & 1 & 0.6 & 0.5 & 0.8481 \\
\hline 6 & Warga16 & 1 & 1 & 1 & 0.6 & 0.5 & 0.8481 \\
\hline 7 & Warga22 & 1 & 1 & 1 & 0.6 & 0.5 & 0.8481 \\
\hline 8 & Warga32 & 1 & 1 & 1 & 0.6 & 0.5 & 0.8481 \\
\hline 9 & Warga34 & 1 & 1 & 1 & 0.6 & 0.5 & 0.8481 \\
\hline 10 & Warga40 & 1 & 1 & 1 & 0.6 & 0.5 & 0.8481 \\
\hline 11 & Warga6 & 1 & 1 & 1 & 0.2 & 0.5 & 0.8257 \\
\hline 12 & Warga27 & 0.75 & 0.5 & 1 & 1 & 1 & 0.8108 \\
\hline 13 & Warga18 & 1 & 1 & 0.5 & 0.6 & 0.5 & 0.8011 \\
\hline 14 & Warga26 & 1 & 1 & 0.5 & 0.6 & 0.5 & 0.8011 \\
\hline 15 & Warga30 & 1 & 1 & 0.5 & 0.6 & 0.5 & 0.8011 \\
\hline 16 & Warga36 & 1 & 1 & 0.5 & 0.6 & 0.5 & 0.8011 \\
\hline 17 & Warga42 & 1 & 1 & 0.5 & 0.6 & 0.5 & 0.8011 \\
\hline 18 & Warga44 & 1 & 1 & 0.5 & 0.6 & 0.5 & 0.8011 \\
\hline 19 & Warga46 & 1 & 1 & 0.5 & 0.6 & 0.5 & 0.8011 \\
\hline 20 & Warga48 & 1 & 1 & 0.5 & 0.6 & 0.5 & 0.8011 \\
\hline
\end{tabular}

Berdasarkan tabel 3.10, maka warga4 merupakan proriotas pertama dalam pemberian bantuan sosial saat pandemi covid 19, kemudian Warga8, warga9, sampai warga48. Sehingga jika RW016 mendapatkan alokasi bantuan dari Kelurahan atau kecamatan, maka Alokasi bantuan tersebut dapat diprioritaskan dari peringkat yang paling teratas atau 1 (satu) sampai dengan yang paling bawah atau 48, sesuai dengan jumlah kuota bantuan sosial yang diterima.

\section{KESIMPULAN}

Penerapan metode Analytical Hierarchy Process (AHP) dan Simple Additive Weighting (SAW) terbukti dapat menentukan rangking penerima bantuan sosial pada saat pandemi Covid-19 yang sesuai dengan kriteria - kriteria yang ditetapkan oleh RT/RW setempat dengan nilai bobot kriteria Status pekerjaan kepala keluarga sebesar 0,425, Status pekerjaan istri sebesar 0,166, Status rumah sebesar 0,094, jumlah tanggungan sebesar 0,056 dan KTP sebesar 0,259 dengan nilai consistency ratio sebesar 0,09.

Penelitian selanjutnya disarankan dapat menggunakan metode pendukung keputusan yang lain dengan jumlah kriteria yang lebih banyak sehingga menghasilkan keputusan yang lebih optimal.

\section{DAFTAR PUSTAKA}

[1] Turban, E., J. E. Aronson, dan T. P. Liang, Decision Support System and Intelligent System. 9th ed. 2010.

[2] Supriatin, S., Wiraatmadja, B. S., dan Luthfi, E. T., "Sistem Pendukung Keputusan Untuk Menentukan Penerima BLSM Di Kabupaten Indramayu", Creative Information Technology Journal, vol. 1, no. 4, pp. 282, 2014.

[3] Parhusip, Jadiaman, "Penerapan Metode Analytical Hierarchy Process (AHP) Pada Desain Sistem Pendukung Keputusan Pemilihan Calon Penerima Bantuan Pangan Non Tunai (BPNT) Di Kota Palangka Raya", Jurnal Teknologi Informasi Jurnal Keilmuan dan Aplikasi Bidang Teknik Informatika, 
vol. 13, no. 2, pp. 18-29, Januari 2019.

[4] Rahardian, R., Hidayat, N., dan Dewi, R. K., "Sistem Pendukung Keputusan Penentuan Penerima Bantuan Keluarga Miskin Menggunakan Metode Analytical Hierarchy Process-Preference Ranking Organization for Enrichment Evaluation II (AHP-PROMETHEE II)", Jurnal Pengembangan Teknologi Informasi dan Ilmu Komputer, vol. 2, no. 5, pp. 1980-1985, Mei 2018.

[5] Putra, Abner Adi, Andreswari, Desi, dan Susilo, Bambang, "Sistem Pendukung Keputusan Untuk Penerima Bantuan Pinjaman Samisake dengan Metode Electre (Studi Kasus LKM Kelurahan Lingkar Timur Kota Bengkulu)", REKURSIF: Jurnal Informatika, vol. 3, no. 1, pp. 1-11, 2015.

[6] Irwana, Chintya, Harahap, Zaki F., dan Windarto, A. P., "Spk: Analisa Metode Moora Pada Warga Penerima Bantuan Renovasi Rumah," Jurnal Teknologi Informasi Mura, vol. 10, no. 1, pp. 47-54, Juni 2018.

[7] Riadi, Joni, Fauzan, Reza, dan Arifianto, Y. P., "Sistem Pendukung Keputusan Penentuan Penerima Raskin Menggunakan Metode Simple Additive Weighting (SAW) Berbasis Web", Jurnal POROS Teknik, vol. 9, no. 2, pp. 23-28, Desember 2017.

[8] Hidayat, Muslim, "Penentuan Pemberian Bantuan Program Keluarga Harapan Dengan Metode Topsis", Jurnal Penelitian dan Pengabdian Kepada Masyarakat UNSIQ, vol. 5, no. 1, pp. 98-106, Januari 2018.

[9] Suryeni, Eni, Agustin, Yoga H., dan Nurfitria, Yuli, "Sistem Pendukung Keputusan Kelayakan Penerimaan Bantuan Beras Miskin Dengan Metode Weighted Product Di Kelurahan Karikil Kecamatan Mangkubumi Kota Tasikmalaya", Konfrensi Nasional Sistem \& Informatika 2015, STMIK STIKOM Bali, 10 Oktober 2015, pp. 345-350.

[10] Wahid, Sukril I., Jamil, M., dan Tempola, Fiman, "Sistem Pendukung Keputusan Kelayakan Penerimaan Bantuan Beras Sejahtera (Rastra) Dengan Menggunakan Metode Weighted Product”, PROtek Jurnal Ilmu Teknik Elektro, vol. 6, no. 2, pp. 68-72, September 2019.

[11] Marimin dan Magfiroh, Teknik dan Aplikasi Pengambilan keputusan dengan Kriteria majemuk. Jakarta: Grasindo, 2010. 